\title{
Alexithymia as a Factor of Somatization of Psychological Problems
}

\section{Алекситимія як чинник соматизації психологічних проблем}

\author{
Natalia Zaviazkina \\ Dr. in Psychology, Assistant Professor, Taras Shevchenko Na- \\ tional University of Kyiv, Kyiv (Ukraine) \\ ORCID ID: https://orcid.org/0000-0001-5565-8959 \\ E-mail: nmuz@ukr.net
}

\section{Наталія Завязкіна}

Доктор психологічних наук, доцент, Київський національний університет імені Тараса Шевченка, м. Київ (Україна)

\section{Anna Vedmedenko}

Master in Psychology, Taras Shevchenko National University of Kyiv, Kyiv (Ukraine)

E-mail: apocalypsana@gmail.com

\section{Анна Ведмеденко}

Магістр психології, Київський національний університет імені Тараса Шевченка, м. Київ (Україна)

The contribution of the author: Zaviazkina N. - 50\%, Vedmedenko A. - 50\%. Авторський внесок: Завязкіна Н. - 50\%, Ведмеденко А. - 50\%.

Address for correspondence, e-mail: kpnu_lab_ps@ukr.net Copyright: (C) Zaviazkina Natalia, Vedmedenko Anna

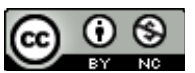

The article is licensed under CC BY-NC 4.0 International

(https://creativecommons.org/licenses/by-nc/4.0/)

(C) Zaviazkina Natalia, Vedmedenko Anna

DOI (article): https://doi.org/10.32626/2227-6246.2020-50.11-30 


\section{ABSTRACT}

The paper notes the urgency of the problem of deeper understanding and research of the relationship between alexithymia and somatic diseases, that may be important for more effective diagnosis, prevention and prediction of professional care for people with psychosomatic diseases. Analysis of the characteristics of people with alexithymia and manifestations of psychosomatic diseases will help to form common criteria that are important to consider at the first visit to a doctor or psychologist.

The purpose of the article is to identify the relationship between alexithymia and personality traits in individuals with a tendency to somatization of psychological problems.

The following methods were used to achieve the tasks: theoretical analysis of the scientific literature, psychodiagnostic and statistical methods corresponding to the research tasks.

The study involved 61 people, 34 women and 27 men among them, voluntarily and anonymously participated in the study.

As a result of the study, the concept of alexithymia and the coverage of this phenomenon in the modern scientific literature are analyzed. The processing of the literature accumulated on this topic made it possible to draw conclusions about the history of the study of alexithymia, its characteristics and manifestations, connections, this phenomenon has with other psychological constructs, as well as to make assumptions about the future direction of this phenomenon.

In the course of empirical research, it was established that there are various connections, in particular the psychological characteristics of persons prone to psychosomatic manifestations. The connection between alexithymia and depression, general distress as a reaction to life's difficulties, as well as irritability and insufficiently formed regulation of the emotional sphere was revealed.

Conclusion. The analysis made it possible to draw conclusions about the characteristics inherent in individuals prone to psychosomatic disorders. Continuing to develop and explore solutions to understanding emotions and emotional self-expression would be interesting from a gender perspective. Further study of alexithymia and somatization and their gender and gender characteristics, in our opinion, should be associated with the completion of a relatively new phenomenon of normative male alexithymia.

Key words: alexithymia, somatic disorders, psychological features, emotional sphere, stress, adaptation, social behavior. 


\section{Introduction}

The development of civilization, changes in lifestyles, the general development of mankind - all and much more facts complicate the process of human adaptation. The number and quality of human characteristics which it must possess in order to find its place and take a safe position in the modern world is growing. In the last decades, as a result of scientific and technological progress, changes have accelerated and society has become increasingly aggressive towards humans. There is a well-established term in sociology to explain this phenomenon - VUCA, which describes the characteristics of the modern world, which is largely unfriendly to humans, abbreviated: Volatility, Uncertainty, Complexity and Ambiguity.

Adaptation is determined by multiple genetic, morphological, physiological and behavioral factors and allows the body to adapt to numerous and varied influences. At the same time, social factors have significant, if not decisive, importance for its successful adaptation. Social behavior increases the chances of an individual to survive and is one of the forms of human adaptation, and emotions are the most important means of self-regulation and social interaction.

A large number of researchers studied issues related to emotional disorders and related somatic disorders, among Ukrainian scientists are V. Nikolaieva (1987), B. Luban-Plotsa (2015), B. Karvasarskyi (2004), O. Chaban (2004), O. Khaustova (2019), I. Malkina-Pykh (2014) and others. Among foreign scientists they are P. Sifneos (1973), G. Taylor (1997), H. Krystal (1988), R. Levant (2009) and others.

The presence of alexithymia, characterized by inadequate processing of emotions, worsens the situation of adaptation and is one of the most important factors in the occurrence of psychosomatic diseases.

A better understanding of the association of alexithymia with somatic illness may be important for more effective diag-

(C) Zaviazkina Natalia, Vedmedenko Anna DOI (article): https://doi.org/10.32626/2227-6246.2020-50.11-30 
nosis, prevention, and prediction of professional care for people with psychosomatic illness. Analysis of the characteristics of people with alexithymia and manifestations of psychosomatic diseases will help to form general criteria that are important for the first visit a doctor or psychologist.

The purpose of the article is to increase the number of alexithymia and special features in particular problems before somatization of psychological problems.

\section{The tasks of the article}

1. To study the theoretical and methodological basis of the concept of alexithymia as a phenomenon of clinical psychology.

2. To highlight the psychological characteristics of persons with somatization of psychological problems.

3. To study empirically the tendency of people to somatize psychological problems and the relationship of this mechanism with the manifestations of alexithymia.

\section{Research methods and techniques}

The research used the theoretical analysis of the scientific literature of Ukrainian and foreign authors; Freiburg Multifactorial Personality Questionnaire (Form B, Adaptation and Modification, 1989 by A. A. Krylov and T. I. Ronginsky), Toronto Alexithymia Scale (TAS-20 R, Adaptation of the Research Institute of Psychiatry), Four-Dimensional Symptom Questionnaire - 4DSQ (Terluin, 1994), anxiety self-assessment scale (Chaban \& Haustova, 2004) and depression self-assessment scale (Chaban \& Haustova, 2004).

\section{Results and discussions}

One of the first who paid attention to the connection between the emotional experiences of a person and his physical bodily complaints within psychosomatics was P. MacLean. He noted that a significant proportion of the psychosomatic patients with whom he worked reported limited ability to use (c) Zaviazkina Natalia, Vedmedenko Anna

DOI (article): https://doi.org/10.32626/2227-6246.2020-50.11-30 
verbal or symbolic signals to discuss and identify their emotions (MacLean, 1949).

The term "alexithymia» (from the Greek A - absence; lexis - word; thymos - emotion) was introduced by the psychotherapist P. Sifneos as a result of summarizing observations of patients in a psychosomatic clinic, and literally means "without words for feelings» (that is lack of words to describe feelings). Common features inherent in such patients were difficulties in identifying their own feelings, finding the right words to describe them, as well as difficulties in distinguishing between feelings and bodily sensations.

According to his description, people suffering from alexithymia are characterized by such features, the ability to perceive their own feelings and emotions, their adequate verbalization and expressive transmission to others is supposed to be combined. They constantly describe physical sensations, often are not associated with any disease, and usually designate their internal sensations as irritability, boredom, emptiness, fatigue, agitation, tension, etc. It is difficult for them to verbalize their own feelings. People with alexithymia are characterized by undeveloped imagination, a tendency to impulsivity, poverty of interpersonal relationships, a sense of boredom and senselessness of contact.

There are several groups of traits characteristic of people with alexithymia:

- disorders of affective and cognitive functions;

- violation of self-awareness;

- especially the manifestation of the world.

Deficiency of cognitive processing of emotion is the basis of the construct of alexithymia. The research suggests that people with high levels of alexithymia perceive words associated with the disease as more emotional than words expressing negative emotions. This tendency to pay attention to words related to the disease is consistent with the idea that the emotions of people with severe alexithymia are insufficiently rep-

(C) Zaviazkina Natalia, Vedmedenko Anna DOI (article): https://doi.org/10.32626/2227-6246.2020-50.11-30 
resented mentally. This in turn leads to their tendency to focus on the somatic sensations that accompany emotional arousal and to misinterpret them as signs of illness. This mechanism underlies the relationship between alexithymia and psychosomatic illness.

According to various sources, there are up to $64 \%$ people with alexithymia among psychosomatic patients. Scientists agree that alexithymia is one of the risk factors for psychosomatic disorders. Modern clinical experience and empirical studies confirm the relationship between alexithymia and psychosomatic diseases, but alexithymia is also characteristic of neurotic disorders, as well as in healthy people.

In general, researchers agree with the division of alexithymia into primary (alexithymia as a trait) and secondary (alexithymia as a condition) for the causes of this disorder, as H. Freyberger was the first to indicate (Freyberger, 1977).

The reasons for the appearance of alexithymic features also remain unclear: they are caused by congenital factors (for example, biochemical deficiency) or due to intravital developmental delays due to family, social and cultural influences (Goerlich, 2018).

It is believed that many factors play a role in the etiology of alexithymia. But alexithymia is considered primary the formation which is associated with deficits in the early development of the child, as indicated by psychoanalytic theorists. Based on this, primary alexithymia is described as an intravital dispositional factor that can lead to the development of psychosomatic illness.

Somatic symptoms have various psychological and social functions, and they are also closely related to the belief system of an individual. Internal conflicts, neurotic types of reactions or psycho-reactive connections determine the picture of organic suffering, its duration, course and even resistance to therapy. It is believed that an erroneous perception of the environment as an aggressor and an overreaction to it can be a (c) Zaviazkina Natalia, Vedmedenko Anna

DOI (article): https://doi.org/10.32626/2227-6246.2020-50.11-30 
key factor in changing the way it is lifted, which leads to poor health and causes illness.

Somatization is a manifestation of a mental disorder in the form of physical (somatic) symptoms. The disorders in which somatization is possible are varied: from those in which the symptoms are formed unconsciously and involuntarily, to those when the symptoms develop quite consciously. This continuum includes somatic symptoms and related disorders, farfetched diseases, and simulation. The unifying characteristic of all these disorders is that patients are primarily concerned about somatic symptoms. In this regard, somatization usually causes patients to seek medical examination and treatment, rather than psychologically or psychiatrically.

Psychosomatic and related disorders are characterized by persistent somatic symptoms occurring against the background of disproportionately intense or maladaptive thoughts, feelings and reactions in response to these symptoms and related health problems. These disorders cause discomfort and often negatively affect the patient's social, professional, educational and other activities. This group of disorders includes conversion disorder, hypochondriacal disorder, psychological factors that affect medical conditions, psychosomatic disorders.

Somatization is considered as a modification of cognitive processes with an emphasis on enhanced perception of bodily sensations and an increased degree of complexity when reporting negative experiences (which in turn requires great cognitive efforts etc.). Somatosensory enhancement and alexithymia are the key elements of the somatization process.

Recurrent somatic complaints usually begin before the age of 30. Most patients have numerous somatic symptoms, but some have only one serious symptom, usually pain. The severity of the symptoms can vary, but they persist for some time, and remission is quite rare. Symptoms or, less commonly, excessive anxiety about them cause serious discomfort to patients and can disrupt daily life, they are a distress for pa-

(C) Zaviazkina Natalia, Vedmedenko Anna DOI (article): https://doi.org/10.32626/2227-6246.2020-50.11-30 
DOI: https://doi.org/10.32626/2227-6246.2020-50

tients themselves and for their families and doctors. In some cases, other disorders may develop on the background of somatic disorders - somatic disorders are distinguished from anxiety and depression.

When a psychosomatic disorder accompanies a somatic illness, patients are overly worried about the consequences of the illness. For example, patients who fully physically recovered from an uncomplicated myocardial infarction may continue to behave as sick or constantly fear the possibility of a new heart attack. Regardless of whether the symptoms are associated with physical illness, patients are overly worried about these symptoms and their possible catastrophic consequences, and it can be very difficult to calm them down. It often happens that attempts to calm them down are perceived by them as a doctor's frivolous attitude to symptoms, which, in turn, causes even greater concern about their own state of health.

Fears for one's health often occupy a central place in the patient's life, and sometimes they begin to play an all-consuming role. Patients are very worried about their health and are often very sensitive to the side effects of exhilaration. Patients with psychosomatic symptoms can become addicted to others, requiring help, emotional support and demonstrate irascibility when their needs are not met by others. They may also threaten suicide or attempt suicide. Such patients are often dissatisfied with the quality of medical care, they usually go from one doctor to another or go to several doctors at once.

In our opinion, it is important to consider the four-dimensional model of psychological symptoms, connect and explain such manifestations of the experience of psychological problems as general distress, depression, anxiety, and somatization. Distinguishing of these phenomena is quite complex. Based on the four-dimensional model of psychological symptoms, distress is considered as the fourth dimension of psychopathology, in the group with depression, anxiety and somatization.

(C) Zaviazkina Natalia, Vedmedenko Anna

DOI (article): https://doi.org/10.32626/2227-6246.2020-50.11-30 
Distress is the most basic, general, most «normal» expression of the experience of psychological problems. In general, distress is independent of depression, anxiety, and somatization. However, these measurements are correlated, probably because stress leads to distress and can also cause disorders that underlie depression, anxiety, or somatization in vulnerable people.

There are two models (Malkina-Pykh, 2014) that explain the syndrome of alexithymia and its role in the formation of psychosomatic disorders. The model of "negation" is based on the idea of global inhibition of affects. According to this model, we can assume the reversibility of alexithymia syndrome. However, in many individuals alexithymic manifestations are irreversible even with long-term and intensive psychotherapy. Such people remain incapable of awareness of emotions and fantasizing. More appropriate thing in such a situation is the "deficit model», according to which there is not inhibition, but the lack of certain mental functions leads to an irreversible decrease in the ability to symbolize instinctive needs and fantasize.

The prevalence of alexithymia in the general population is about $10 \%$, while among the patients with psychosomatic disorders reported a significantly higher rate of alexithymia (approximately 40-60\%) (Taylor, 1997). Alexithymia is considered a key factor associated with the development of the psychosomatic process, and is also one of the neurological causes of physical illness (Taylor, 1991).The phenomenon of alexithymia is associated with increased mortality, primarily among men (Kauhanen, 1996).

The mechanism underlying alexithymia and its relationship to somatic diseases remains unclear. Today several possible explanations have been proposed, including the following: alexithymia leads to organic disease through physiological or behavioral mechanisms; alexithymia leads to painful behavior

(C) Zaviazkina Natalia, Vedmedenko Anna DOI (article): https://doi.org/10.32626/2227-6246.2020-50.11-30 
DOI: https://doi.org/10.32626/2227-6246.2020-50 2020. випуск 50

(such as the presence of physical symptoms, loss of ability to work, excessive treatment) through cognitive or social mechanisms; somatic disease leads to the development of alexithymia; alexithymia as well as somatic diseases are the consequence of sociocultural or biological factors (Lumley, 1996).

The relations between alexithymia, psychosomatic illnesses, and the defense mechanisms used by a person in stressful situations are also important. Instead of using neurotic remedies, people with alexithymia are more likely to use primitive defense mechanisms, such as cleavage, projective identification, and, in fact, somatization (Parker, 1998).

The research involved 61 people, 34 women and 27 men among them, voluntarily and anonymously participated in the study, conducted in the form of online testing.

Analysis of statistical data showed significant direct proportions of alexithymia with such characteristics as depression $(r=0.29 ; p=0.02)$, irritability $(r=0.43 ; p=0.00)$, distress $(r=0.25 ; p=0.04)$ and self-assessment of depression $(\mathrm{r}=0.32 ; \mathrm{p}=0.01)$.

Analyzing the obtained data, it can be noted that alexithymia is associated with depressed mood and self-esteem of the same study of their own state as depressed. These results are consistent with the available information on the direct link between depression and alexithymia, that is individuals for whom the identification and expression of emotions is quite a difficult task, more often show symptoms of depressive disorders - depressed mood, pessimistic assessment of themselves and others and the like. Also, people with high levels of alexithymia have unexplained physical experiences with somatic diseases.

The direct relationship between the total alexithymia score and the distress index indicates that those subjects who have higher alexithymia scores, that is they have difficulty processing, identifying, understanding emotions, show more pronounced distress, they are characterized by maladaptive expe(C) Zaviazkina Natalia, Vedmedenko Anna

DOI (article): https://doi.org/10.32626/2227-6246.2020-50.11-30 
DOI: https://doi.org/10.32626/2227-6246.2020-50 2020. випуск 50

rience of psychological difficulties and general reaction the distress associated with them. At the same time, those of the subjects who had low rates of alexithymia were prone to less distress. Taking into account the data of correlation, we can assume that the presence of distress in life of certain individuals can lead to secondary alexithymia - a violation of the assessment of their own emotional sphere, may be due in part to the work of protective mechanisms that block the expression of emotions.

The strongest relationship of the total score on the scale "Alexithymia» was obtained with the indicator "Irritability". High scores on this scale indicate the instability of the emotional state with a tendency to react affectively. Accordingly, analyzing this relationship, we can say that the emotional self-regulation of subjects with high rates of alexithymia is unstable, unsatisfactory and limited, and has the form of irritability, aggression. Individuals who have difficulty identifying their feelings have general emotional instability and decreased self-control, and conversely, the better the subjects are oriented in their emotional sphere, the more productive and easier for them the emotional self-regulation is, they are not characterized by emotional outbursts and tension.

An inversely proportional relationship was found between alexithymia and sociability $(\mathrm{r}=-0.26, \mathrm{p}=0.03)$. Accordingly, those of the subjects with pronounced alexithymia, firstly, have fewer social connections in general, and secondly - express less need and willingness to communicate with others, they show a tendency to avoid contact.

Decreased communication needs and abilities associated with the presence of alexithymic manifestations may be due to the fact that in violation of the processing of emotions, communication with other people may not be pleasant as such, due to which such persons do not show social activity. Emotional self-regulation and understanding of the interlocutor's emotions, necessary for adequate communication, are disturbed in

(C) Zaviazkina Natalia, Vedmedenko Anna DOI (article): https://doi.org/10.32626/2227-6246.2020-50.11-30 
alexithymia, so the inversely proportional relationship we received is logically understandable.

The identified relationship also confirms our suggestions about the great difficulties that arise with people with alexithymia when it is necessary to maintain friendly relations with other people. This connection also indicates that people with low rates of alexithymia, that is, those who are well versed in their emotions and can identify, name them, have better relationships with others and generally more willing to socialize.

For better understanding of the issue, in addition to the analysis of the relations with the total alexithymia score, correlations were also calculated for individual scales of the TAS-20 method. When analyzing the cognitive components of the alexithymia construct, such as "complexity of describing feelings» and «external thinking", the following results were obtained: for the indicator "Complexity of describing feelings» the correlations generally coincided with the relationships found for the overall alexithymia index. That is, individuals who had difficulty describing their feelings were prone to unstable emotional self-regulation and incontinence, and generally described their condition as depressive. The feedback obtained with the indicator of sociability confirms the fact that insufficiently developed skills of identification and verbalization of feelings negatively affect the quality of communication and social activity of the individual as a whole. We suggest that the connections obtained with self-assessment of depression and communicativeness can be analyzed together. Thus, probably, the lack of adequate and close communication, through alexithymia, can, among other things, lead to depressive tendencies, further isolation and deterioration of the condition of such persons.

To clarify the links between the somatization of psychological problems and the personal characteristics of the subjects, a correlation analysis was performed. For the indicator «Somatization», which describes the severity of psychosomatic (C) Zaviazkina Natalia, Vedmedenko Anna

DOI (article): https://doi.org/10.32626/2227-6246.2020-50.11-30 
manifestations, we obtained the following results: the directly proportional connection between the indicator of somatization and the indicator of neuroticism indicated a characteristic of people with psychosomatic disorders, neuroticism and asthenia, lack of motivation and energy. Such individuals are susceptible to random mood swings and sensitive to criticism and comments. For the indicator of somatization, there was also a direct link with depression. That is, people prone to the manifestations of somatophore disorders were characterized by the presence of depressive symptoms in the emotional state, behavior, attitude to themselves and others.

Analyzing the direct relationship between somatization and «irritability», we can say that along with alexithymia, the group of traits inherent in people with psychosomatic disorders also includes emotional explosiveness, tension and reduced ability to self-control. At the same time, the inverse relationship between somatization and the indicator of «balance» provides an opportunity to characterize individuals with existing psychosomatic disorders as limitedly able to cope with stressful situations, self-control and self-regulation. That is, we can say that the tendency to somatize psychological problems is associated with weak psychological protection from stressors, passivity and pessimism. In the cases where self-control and self-regulation are weak, somatization reaction to stressful situations is more likely.

In order to analyze the relationships between personality traits and manifestations of alexithymia and the tendency to somatization of psychological problems, we conducted a factor analysis, which identified two independent factors.

The first «Emotional factor» included the following characteristics: emotional lability $(\mathrm{r}=0.85)$; distress $(\mathrm{r}=0.83)$; depression ( $r=0.80)$; neuroticism $(r=0.78)$; self-assessment of anxiety $(\mathrm{r}=0.77)$; self-assessment of depression $(\mathrm{r}=0.77)$; somatization $(r=0.64)$; anxiety $(r=0.64)$; shyness $(r=0.60)$;

(C) Zaviazkina Natalia, Vedmedenko Anna DOI (article): https://doi.org/10.32626/2227-6246.2020-50.11-30 
DOI: https://doi.org/10.32626/2227-6246.2020-50

balance $(r=-0.60)$; depression $(r=0.58)$; difficulty identifying feelings $(r=0.51)$.

The second factor «Personal characteristics» comprised the following characteristics: extraversion-introversion $(\mathrm{r}=0.67)$; external thinking $(\mathrm{r}=0.64)$; masculinity-femininity $(\mathrm{r}=0.60)$; alexithymia $(r=0.59)$; irritability $(r=0.53)$.

Thus, the first factor included characteristics associated with emotional instability, self-doubt, distress. The second factor included characteristics in terms of a pronounced cognitive focus on the external world, and, accordingly, a certain inattention to one's inner state and the world of inner experiences.

\section{Conclusions}

During the research, the concept of alexithymia and coverage of this phenomenon in the scientific literature of both Ukrainian and foreign scientists were analyzed. The processing of the literature on this topic allows to draw conclusions about the history of alexithymia, its characteristics and manifestations, connections, this phenomenon has with other psychological constructs, as well as to make assumptions about the future direction in the study of this phenomenon.

An empirical study was conducted, the results of which established the presence of various relationships, in particular the psychological characteristics of people prone to psychosomatic manifestations. Thus, according to the results of our study, the connection between alexithymia and depression, general distress as a reaction to life difficulties, as well as irritability and insufficiently formed regulation of the emotional sphere was found.

The alexithymia was found to have an inverse relationship with sociability. People with severe emotional difficulties are less likely to communicate with others, do not know how to do it, or get much less pleasure from it than people who do not have alexithymia.

(C) Zaviazkina Natalia, Vedmedenko Anna

DOI (article): https://doi.org/10.32626/2227-6246.2020-50.11-30 
The analysis made it possible to draw conclusions about the characteristics inherent in individuals prone to psychosomatic disorders.

Continuing to develop and explore solutions to understanding emotions and emotional self-expression would be interesting from a gender perspective. Further study of alexithymia and somatization and their gender and gender characteristics, in our opinion, should be associated with the researching of a relatively new phenomenon of normative male alexithymia.

\section{Literature}

Карвасарский Б. Д. Клиническая психология. Санкт-Петербург : Питер, 2004. 553 с.

Любан-Плоцца Б., Пельдингер В., Крегер Ф., Ледерах-Хофман К. Психосоматические расстройства в общей медицинской практике. Санкт-Петербург : Лита, 2005, 288 с.

Малкина-Пых И. Г. Психосоматика: Справочник практического психолога. Москва : Эксмо, 2004, 214 с.

Николаева В. В. Влияние хронической болезни на психику. Москва : Издательство Московского университета, 1987. 168 с.

Хаустова О. О. Психосоматичні маски тривоги. Украӥнський медичний часопис. 2019. № 4 (1) (132) - VII/VIII. URL : https://www.umj. com.ua/article/160744/psihosomatichni-maski-trivogi.

Чабан О. С., Хаустова О. О. Психосоматична медицина (аспекти діагностики та лікування). Київ : Медкнига, 2005. 96 с.

Freyberger, H. (1997). Supportive psychotherapeutic techniques in primary and secondary alexithymia. Psychotherapy and Psychosomatics. № 28. S. 337-342.

Goerlich, K. S. (2018). The Multifaceted Nature of Alexithymia. A Neuroscientific Perspective. Frontiers in Psychology. URL : https://www. ncbi.nlm.nih.gov/pmc/articles/PMC6124373/.

Kauhanen, J., Kaplan, G., \& Cohen, R. (1996). Alexithymia and risk of death in middle-aged men. Journal of Psychosomatic Research. № 41 (6). S. 541-549.

Krystal, H., \& Hillsdale, N. J. (1988). Integration and Self-Healing: Affect, Trauma, and Alexithymia. Hillsdale : Analytic Press, NJ. 198 s.

Levant, R. F., Hall, R. J., Williams, C. M., \& Hasan, N. T. (2009). Gender differences in alexithymia. Psychology of Men \& Masculinity. № 10 (3). S. $190-203$.

(C) Zaviazkina Natalia, Vedmedenko Anna

DOI (article): https://doi.org/10.32626/2227-6246.2020-50.11-30 
Levant, R. F., Good, G. E., \& Cook, S. W. (2006). The normative Male Alexithymia Scale: Measurement of a gender-linked syndrome. Psychology of Men \& Masculinity. № 7. S. 212-224.

Lumley, M. A., Stettner, L., \& Wehmer, F. (1996). How are alexithymia and physical illness linked? A review and critique of pathways. Journal of Psychosomatic Research. № 41 (6). S. 505-518.

MacLean, P. D. (1949). Psychosomatic disease and the visceral brain; recent developments bearing on the Papez theory of emotion. Psychosomatic Medicine. № 11. S. 338-353.

Parker, J. D., Taylor, G. J., \& Bagby, R. M. (1998). Alexithymia: Relationship with ego defense and coping styles. Comprehensive Psychiatry. № 39. S. 91-98.

Sifneos, P. E. (1973). The prevalence of «alexithymic» characteristics in psychosomatic patients. Psychotherapy and Psychosomatics. № 22. S. $255-262$.

Taylor, G. J., Bagby, R. M., \& Parker, J. D. (1997). Disorders of Affect Regulation: Alexithymia in Medical and Psychiatric Illness. Cambridge : Cambridge University Press. $199 \mathrm{~s}$.

\section{References}

Karvasarskii, B. D. (2004). Klinicheskaia psikhologiia [Clinical psychology]. Sankt-Peterburg : Piter [in Russian].

Luban-Plozza, B., Peldinger, V., Kreger, F., \& Lederakh-Hoffman, K. (2005). Psikhosomaticheskiie rasstroistva $v$ obshchei meditsinskoi praktike [Psychosomatic disorders in general medical practice]. Sankt-Peterburg : Lita [in Russian].

Malkina-Pykh, I. G. (2004). Psikhosomatika: Spravochnik prakticheskogo psikhologa [Psychosomatics: a Practical Psychologist Handbook]. Moskva : Eksmo [in Russian].

Nikolaieva, V. V. (1987). Vliianiie khronicheskoi bolezni na psikhiku [The effect of chronic disease on the psyche]. Moskva : Izdatelstvo Moskovskogo universiteta [in Russian].

Khaustova, O. O. (2019). Psykhosomatychni masky tryvohy [Psychosomatic masks of anxiety]. Ukrainskyi medychnyi chasopys - Ukrainian Medical Journal, 4 (1) (132) - VII/VIII. Retrieved from https:// www.umj.com.ua/article/160744/psihosomatichni-maski-trivogi [in Ukrainian].

Chaban, O. S., \& Khaustova, O. O. (2005). Psykhosomatychna medytsyna (aspekty diagnostyky ta likuvannia) [Psychosomatic medicine (an aspect of diagnosis and treatment)]. Kyiv : Medknyga [in Ukrainian].

(C) Zaviazkina Natalia, Vedmedenko Anna

DOI (article): https://doi.org/10.32626/2227-6246.2020-50.11-30 
Freyberger, H. (1977). Supportive psychotherapeutic techniques in primary and secondary alexithymia. Psychotherapy and Psychosomatics, $28,337-342$.

Goerlich, K. S. (2018). The Multifaceted Nature of Alexithymia. A Neuroscientific Perspective. Frontiers in Psychology. Retrieved from https://www.ncbi.nlm.nih.gov/pmc/articles/PMC6124373/.

Kauhanen, J., Kaplan, G., \& Cohen, R. (1996). Alexithymia and risk of death in middle-aged men. Journal of Psychosomatic Research, 41 (6), 541-549.

Krystal, H., \& Hillsdale, N. J. (1988). Integration and Self-Healing: Affect, Trauma, and Alexithymia. Hillsdale : Analytic Press.

Levant, R. F., Hall R. J., Williams, C. M., \& Hasan, N. T. (2009). Gender differences in alexithymia. Psychology of Men \& Masculinity, 10 (3), 190-203.

Levant, R. F., Good, G. E., Cook, S. W., O’Neil, J. M., Smalley, K. B., Owen, K., et al. (2006). The Normative Male Alexithymia Scale: Measurement of a gender-linked syndrome. Psychology of Men \& Masculinity, 7, 212-224.

Lumley, M. A., Stettner, L., \& Wehmer, F. (1996). How are alexithymia and physical illness linked? A review and critique of pathways. Journal of Psychosomatic Research, 41 (6), 505-518.

Maclean, P. D. (1949). Psychosomatic disease and the visceral brain; recent developments bearing on the Papez theory of emotion. Psychosomatic Medicine, 11, 338-353.

Parker, J. D., Taylor, G. J., \& Bagby, R. M. (1998). Alexithymia: Relationship with ego defense and coping styles. Comprehensive Psychiatry, 39 (2), 91-98.

Sifneos, P. E. (1973). The prevalence of «alexithymic» characteristics in psychosomatic patients. Psychotherapy and Psychosomatics, 22 (2-6), 255-262.

Taylor, G. J., Bagby, R. M., \& Parker, J. D. (1997). Disorders of Affect Regulation: Alexithymia in Medical and Psychiatric Illness. Cambridge : Cambridge University Press.

Завязкіна Наталія, Ведмеденко Анна. Алекситимія як чинник соматизації психологічних проблем

\section{АНОТАЦІЯ}

У роботі наголошено на актуальності проблеми глибшого розуміння та дослідження зв'язку алекситимії з соматичними захворюваннями, що

(C) Zaviazkina Natalia, Vedmedenko Anna DOI (article): https://doi.org/10.32626/2227-6246.2020-50.11-30 
може бути важливим для ефективнішої діагностики, профілактики $i$ прогнозування надання професійної допомоги особам, які мають психосоматичні захворювання. Аналіз характеристик, притаманних особам з алекситимією та проявами психосоматичних захворювань, допоможе сформувати загальні критерії, які ванливо враховувати при першому зверненні до лікаря або психолога.

Мета статті полягає у виявленні зв'язку між алекситимією й особистісними особливостями в осіб зі схильністю до соматизації психологічних проблем.

Для досягнення завдань використано такі методи: теоретичний аналіз наукової літератури, відповідні задачам дослідження психодіагностичні та статистичні методи.

У дослідженні добровільно й анонімно взяла участь 61 особа (34 жінки та 27 чоловіків).

У результаті дослідження проаналізовано поняття алекситимії та висвітлення цього феномену в сучасній науковій літературі. Опраиювання накопиченої з порушеної теми літератури надало змогу зробити висновки щодо історії дослідження алекситимії, ії характерних рис і проявів, зв'язків, які окреслений феномен має з іншими психологічними конструктами, а також висловити припущення стосовно майбутнього напрямку в дослідженні цього феномену.

У ході проведеного емпіричного дослідження було встановлено наявність різноманітних зв'язків, зокрема психологічних особливостей осіб, схильних до психосоматичних проявів. Виявлено зв'язок алекситимії з депресивністю, загальним дистресом як реакцією на життєві складнощі, а також дратівливістю та недостатньо сформованою регуляцією емоційної срери.

Проведений аналіз надав змогу зробити висновки щодо характеристик, притаманних особам, схильним до психосоматичних порушень. Продовження розробки й вивчення можливостей вирішення питань розуміння емоцій та емоційного самовираження було б цікавим із позицій вивчення гендерних особливостей. Подальше дослідження алекситимії й соматизації та їх гендерних і статевих особливостей, на наш погляд, має бути пов'язано з дослідженням порівняно нового феномену - нормативної чоловічої алекситимії.

Ключові слова: алекситимія, соматичні розлади, психологічні особливості, емочійна сфера, стрес, адаптація, сочіальна поведінка.

C Zaviazkina Natalia, Vedmedenko Anna

DOI (article): https://doi.org/10.32626/2227-6246.2020-50.11-30 
DOI: https://doi.org/10.32626/2227-6246.2020-50

2020. випуск 50

Завязкина Наталия, Ведмеденко Анна. Алекситимия как фактор соматизации психологических проблем

\section{АННОТАЦИЯ}

В работе подчеркнута актуальность проблемы более глубокого понимания и исследования связи алекситимии с соматическими заболеваниями, что может иметь большое значение для более эффективной диагностики, профилактики и прогнозирования оказания профессиональной помощи лицам, которые имеют психосоматические заболевания. Анализ характеристик, присущих лицам с алекситимией и проявлениями психосоматических заболеваний, поможет выделить и сорормировать общие критерии, которые важно учитывать при первом обращении к врачу или психологу.

Цель статьи заключается в выявлении связи между алекситимией и личностными особенностями у лиц со склонностью к соматизации психологических проблем.

Для достижения задач были использованы следующие методы: теоретический анализ научной литературы, соответствующие задачам исследования психодиагностические и статистические методы.

В исследовании добровольно и анонимно принял участие 61 человек (34 женщины и 27 мужчин).

В результате исследования проанализированы понятие алекситимии и освещение данного феномена в современной научной литературе. Обработка накопленной по поднятой теме литературы дала возможность сделать выводы, касающиеся истории исследования алекситимии, ее характерных черт, проявлений и связей. Все вышеуказанное, а также проведенное эмпирическое исследование, выявило тесную связь изучаемого феномена с другими психологическими конструктами, а также позволило сделать предположения относительно будущего направления в его изучении.

В ходе проведенного эмпирического исследования было установлено наличие значимых корреляционных связей, в частности, связь алекситимии и психологических особенностей лии, склонных к психосоматическим проявлениям. Была выявлена значимая связь алекситимии с депрессивностью, общим уровнем дистресса как реакцией на жизненные сложности, а также раздражительностью и недостаточно сформированной регуляцией эмоциональной сферы.

(C) Zaviazkina Natalia, Vedmedenko Anna DOI (article): https://doi.org/10.32626/2227-6246.2020-50.11-30 
DOI: https://doi.org/10.32626/2227-6246.2020-50 2020. ВипУСК 50

Проведенный анализ предоставил возможность сделать выводы в отношении психологических характеристик, присущих лицам, склонным к психосоматическим нарушениям. Продолжение этих разработок и изучения возможностей решения вопросов понимания эмоций и эмоционального самовыражения было бы интересным с точки зрения изучения гендерных особенностей. Дальнейшее исследование алекситимии и соматических нарушений, их связи с гендерными особенностями может быть связано с исследованием относительно нового феномена - нормативной мужской алекситимии.

Ключевые слова: алекситимия, расстройство, психологические особенности, эмоциональная срера, стресс, адаптация, сочиальное поведение.

Original manuscript received June 02, 2020 Revised manuscript accepted July 18, 2020

(C) Zaviazkina Natalia, Vedmedenko Anna

DOI (article): https://doi.org/10.32626/2227-6246.2020-50.11-30 http://journals.uran.ua/index.php/2227-6246 